\title{
Phosphorus body content in an herbivorous fish in environments with different trophic state
}

\author{
Talita M. DE ANDRADE SANTOS, ${ }^{1}$ Bianca DE FREITAS TERRA, ${ }^{1}$ Eugenia ZANDONÀ,,${ }^{2}$ Sandra T. SANTAELLA, ${ }^{3}$ \\ Carla F. REZENDE ${ }^{*}$
}

${ }^{1}$ Programa de Pós-Graduação em Ecologia e Recursos Naturais, Departamento de Biologia, Universidade Federal do Ceará, Campus do Pici, Centro de Ciências, Bloco 902, CEP 60.455-760, Fortaleza, Ceará, Brazil; ${ }^{2}$ Departamento de Ecologia, IBRAG, Universidade do Estado do Rio de Janeiro, Rio de Janeiro, Brazil; ${ }^{3}$ Instituto de Ciências do Mar, Universidade Federal do Ceará, Ceará, Brazil *Corresponding author: carlarezende.ufc@gmail.com

\begin{abstract}
Animals are thought to be homeostatic, as they maintain relatively constant body nutrient content independently of changes in diet. Phosphorus $(P)$ is one of the most important elements for fishes such as loricariids, which are covered with armor-like bony plates. These species are expected to maintain nutrient homeostasis, however, in environments with low P availability they can be Plimited. The hypothesis of this study is that P body content of the herbivorous loricariid fish Hypostomus jaguribensis does not change in environments with different availability of this nutrient. We conducted this study in two locations of the Curu river basin in Brazil, which differed in their nutrient concentrations: one was ultraoligotrophic and the other mesotrophic, as determined by total phosphorous concentrations and chlorophyll a in the water. We found significant differences in the body P content of the fish from the two sites: Hypostomus jaguribensis from the ultraoligotrophic site showed higher body P content, higher body weight and condition factor. This suggests that the ultraoligotrophic site is a more favorable environment for this species. The body P content was higher in fish of intermediate sizes (between 12 and $14 \mathrm{~cm}$ in the ultraoligotrophic site and between 11 and $13 \mathrm{~cm}$ in the mesotrophic site), which can be related to biological characteristics such as the need to accumulate nutrients at the beginning of the reproductive period. Our study did not find support for strict homeostasis in this high-P demand fish species.
\end{abstract}

Key words: Trophic state index; catfish; ecological stoichiometry.

Received: March 2015. Accepted: March 2016.

\section{INTRODUCTION}

Stoichiometry theory assumes that animal species maintain relatively constant body nutrient content per unit body mass, and that the nutrient content and assimilation efficiency of consumers are relatively constant and independent from variation in food quality and ingestion rate (Sterner and Elser, 2002; McIntyre and Flecker, 2010). This ability of a heterotrophic organism to maintain its body elemental composition relatively constant, despite varying diets, is defined as homeostasis (Sterner and Elser, 2002). However, some studies have pointed out that in animal species organismal stoichiometry may not be as constant as previously thought, so that consumers may not be strictly homeostatic (Hendrixson et al., 2007; Boros et al., 2012, 2015; El-Sabaawi et al., 2012a; El-Sabaawi et al., 2012b; Benstead et al., 2014).

Fish are especially interesting to study with a stoichiometric perspective, because they often have high biomasses and they thus represent important sources of nutrients for primary producers via their excretion (Vanni et al., 2002). Excretion rates depend on the balance between the fish diet and their body nutrient con- tent (Vanni et al., 2002; Vanni, 2002). But fish can also represent nutrient sinks, due to their high nutrient demand and high biomass (McIntyre and Flecker, 2010; Vanni et al., 2013). It is thus important to study the factors that control fish elemental content, to understand their role as nutrient recyclers in the ecosystem.

Deviations from strict homeostasis in elemental content has been observed among individuals within a single species and can arise from several sources, such as sex, life stage and ontogeny, diet quality, stress, and feeding history (Hendrixson et al., 2007; El-Sabaawi et al., 2012a, 2012b; Benstead et al., 2014; Dalton and Flecker, 2014; El-Sabaawi et al., 2014; Boros et al., 2015). For instance, studies on Trinidadian fish [Rivulus hartii (Boulenger, 1890)] and guppies [Poecilia reticulata (Peters, 1859)] showed that local environmental conditions and spatial variability in elemental availability were a stronger predictor of organismal stoichiometry than the fish phenotype (El-Sabaawi et al., 2012a,b; El-Sabaawi et al., 2014). Roaches (Rutilus rutilus L.) belonging to different lakes in Europe have been shown to vary in their elemental content, which was correlated with lake productivity (Boros et al., 2012). From these studies it emerges that environ- 
mental factors can be important in regulating animals' elemental demand.

Phosphorus is one of the most important elements used to build living beings, and its uptake from the environment is consequently essential for all organisms (Sardans et al., 2012). For fishes, besides nucleic acids that contain significant amount of $\mathrm{P}$, bones and scales are also rich in this element (Vrede et al., 2004; Hendrixson et al., 2007). Loricariids, a common Neotropical fish family, are covered with armor-like bony plates, which lead to high body P concentrations (4-6\%; McIntyre and Flecker, 2010), and therefore high $\mathrm{P}$ demand (Capps and Flecker, 2013). In environments with low $\mathrm{P}$ availability, loricariids can thus be P-limited (Hood et al., 2005; Capps and Flecker, 2013), even maintaining nutrient homeostasis. The role of loricariids in the ecosystem as P sources of sinks can thus depend on their body elemental content and on the nutrient concentrations in the environment.

The aim of this study is to test whether P body content in the loricariids Hypostomus jaguribensis (Fowler, 1915) is affected by the environment trophic status. To assess the potential intraspecific variation in $\mathrm{P}$ body content, we collected fish from two sites of the same catchment area, which presented different productivity levels and nutrient concentrations. We measured $\mathrm{P}$ body content of adult $H$. jaguribensis and also evaluated if it was associated with fish body size and body condition. If $H$. jaguribensis is strictly homeostatic, its body $\mathrm{P}$ content should not be affected by eutrophication level.

\section{METHODS}

\section{Study area}

This study was conducted in the Curu River basin, Northeastern Brazil. This basin has low water levels during the year and is subject to the effects of rainfall irregularities in the semi-arid region. The average annual rainfall is around $801 \mathrm{~mm}$, evaporation of $1475 \mathrm{~mm}$, and average annual temperature around $27.1^{\circ} \mathrm{C}$ (Gorayeb et al., 2006). Fish were collected in an artificially perennial reach of the river Curu $\left(03^{\circ} 49^{\prime} 04.5^{\prime \prime} \mathrm{S}\right.$ and $39^{\circ} 19^{\prime} 55.4^{\prime \prime}$ $\mathrm{W})$ and in the Xixá reservoir $\left(03^{\circ} 48^{\prime} 28.83^{\prime \prime} \mathrm{S}\right.$ and $39^{\circ} 20^{\prime}$ $\left.30.7^{\prime \prime} \mathrm{W}\right)$. The latter is a small reservoir in the Curu river basin, with capacity below $10 \mathrm{hm}^{3}$. This reservoir is subject to anthropogenic changes (e.g., fishing, agriculture, livestock and deforestation) and has no riparian vegetation due to deforestation, thus increasing runoff.

\section{Trophic state index}

To characterize the trophic state of the two sites studied we used the trophic state index (TSI), proposed by Carlson (1977). This index classifies water bodies in different trophic degrees, estimating water quality based on its nutrient concentration. Three variables are proposed for the calculation of the TSI (transparency, chlorophyll $a$, and total phosphorus), but we only used chlorophyll $a$ and total phosphorus. Transparency was not included because it can be affected by turbidity due to suspended inorganic material; thus, its values are not representative of the state of hypertrophy (Zagatto et al., 1999). The equations used to calculate the TSI were the same used by CETESB (Companhia Ambiental do Estado de São Paulo), following the changes proposed by Toledo et al. (1983) to adapt them to tropical rivers.

\section{For Curu river:}

TSI $(C L)=10 x(6-((-0.7-0.6 x(\ln C L)) / \ln 2))-20$
TSI $(\mathrm{TP})=10 \times(6-((0.42-0.36 x(\ln T P)) / \ln 2))-20$

For Xixá reservoir:

TSI $(C L)=10 x(6-((0.92-0.34 x(\ln C L)) / \ln 2))$ TSI $(\mathrm{TP})=10 \times(6-((1.77-0.42 \times(\ln \mathrm{TP})) / \ln 2)) \quad$ (eq. 4$)$

where $\mathrm{TP}=$ total phosphorus concentration measured at the surface of the water, in $\mu \mathrm{g} \mathrm{L}^{-1}$; $\mathrm{CL}=$ chlorophyll $a$ concentrations measured at the surface of the water in $\mu \mathrm{g} \mathrm{L}^{-1}$, and $\ln =$ natural logarithm. The determination of the TSI is the simple arithmetic average of the indices for total phosphorus and chlorophyll $a$ according to this equation:

TSI $=[$ TSI $(\mathrm{TP})+\mathrm{TSI}(\mathrm{CL})] / 2$

(eq. 5)

\section{Water sampling and nutrient analysis}

For the determination of the nutrient concentrations, two samples of $1 \mathrm{~L}$ of water were taken at each site, approximately in the middle of the water column near the surface. These samples were taken at the same time of the fish sampling, between January and February 2013. As we were not investigating seasonal variation, we just collected water and fish in the wet season. The jars were covered with aluminium foil to avoid altering the concentration of chlorophyll $a$ in the sample due to the continuity of the process of photosynthesis in the presence of light. After collection, the samples were stored in polystyrene boxes with ice and kept at low temperatures $\left(>4^{\circ} \mathrm{C}\right)$ until they were taken to the Laboratório de Efluentes e Qualidade de Água (EQUAL), Universidade Federal do Ceará, where the analytical procedures were performed.

Following the methods proposed by Eaton et al. (2005), the concentration of ammonium (Phenate - 4500$\mathrm{NH}_{3} \mathrm{~F}$ ), nitrate (Cadmium reduction - 4500- $\mathrm{NO}_{3} \mathrm{E}$ ), nitrite (Colorimetric 4500- $\mathrm{NO}_{2}$ B), orthophosphate (Ascorbic acid - 4500-P B.5), total phosphorus (Persulfate digestion and flow injection analysis for total phosphorus - 4500-P J; 4500-P E) and chlorophyll a (Epectrophotometric $(10200 \mathrm{H})$ was determined in water samples. Dis- 
solved oxygen was determined by multiparameter probe YZI 6600 V2-2 model.

\section{Fish sampling and nutrient analysis}

Thirty-one and 32 specimens were caught between January and February 2013 in the Curu river and Xixá reservoir, respectively. Fishes were collected with gillnets (mesh size 50-60 mm) and casting net (mesh size 40 $\mathrm{mm}$ ). All individuals were anesthetized with eugenol (clove oil, $0.4 \mathrm{~mL}$; methyl alcohol, $3.6 \mathrm{~mL}$; and water, $1.996 \mathrm{~mL}$ ) and transported on ice to the laboratory, where they were stored in $-20^{\circ} \mathrm{C}$. Total length $(\mathrm{TL} ; \mathrm{cm})$, standard length (SL; cm), and total weight (TW; g) were measured. Fishes were dried whole in a drying oven at $60^{\circ} \mathrm{C}$ for three days. We did not remove the digestive trait, because the fishes had the time to at least partially empty their stomach before being sacrificed. After drying, the material was homogenized to form a fine, dry powder to determine body $\mathrm{P}$ concentration. All samples were standardized to $3.0 \mathrm{mg}$ diluted in $10 \mathrm{~mL}$ of MilliQ water from which 5 microliters were taken for reading. Particulate $\mathrm{P}$ analysis from fish tissue was performed using $\mathrm{HCl}$ digestion followed by soluble reactive phosphorus (SRP) analysis (Stainton et al., 1977).

\section{Condition factor}

Environmental conditions can influence length, mass and physiological state of the fish. Thus, the condition factor $(\mathrm{K})$ provides important information, because it indicates the degree of well-being of fish in the environment in which it lives (Froese, 2006). The condition factor assumes that larger mass of individuals in a given length are better biological conditions (Froese, 2006). Thus, the value of $b$ from the length-mass relationship [TW (total wet mass) $=\mathrm{aSL}^{\mathrm{b}}$ ] was used to calculate the condition fac- tor. Individual values of the condition factor were obtained through the formula $\mathrm{K}=\mathrm{TW} / \mathrm{SL}^{\mathrm{b}}$.

\section{Data analysis}

Student's $t$-test was used to assess if there were differences between the two sites in three response variables: i) P body content; ii) weight; and iii) condition factor between the two studied sites (grouping variables). We used linear regression to test for a possible relationship between $P$ content (dependent variable) and fish length (independent variable). We ran all statistics analysis in $\mathrm{R}$ (ver. 3.1.2; R Development Core Team, Vienna, Austria).

\section{RESULTS}

All nutrients showed higher concentrations in Xixá reservoir and dissolved oxygen showed higher concentrations in the Curu river (Tab. 1). According to the trophic state index (TSI), the Xixá reservoir was classified as mesotrophic and the Curu river as ultraoligotrophic (Tab. 1). From now on the Xixá reservoir is referred to as the mesotrophic site and the Curu river as the ultraoligotrophic site.

The average mass of $H$. jaguribensis was significantly higher in the ultraoligotrophic site compared to the mesotrophic site $(\mathrm{t}=7.3 ; \mathrm{df}=59.38 ; \mathrm{P}<0.01)($ Tab. 2$)$. The condition factor was significantly higher for individuals from the ultraoligotrophic site than those from the mesotrophic site $(\mathrm{t}=-27.98 ; \mathrm{df}=37.09 ; \mathrm{P}<0.01)$ (Tab. 2).

Higher body $\mathrm{P}$ content were observed in individuals from the ultraoligotrophic site compared to the mesotrophic site $(\mathrm{t}=6.08 ; \mathrm{df}=39.88 ; \mathrm{P}<0.01)$. In both sites, there is no linear relationship between $\mathrm{P}$ content and length $\left(\mathrm{R}^{2}=0.10 ; \mathrm{F}_{1,24}=2.79 ; \mathrm{P}>0.05\right.$ for ultraoligotrophic site and $\mathrm{R}^{2}=0.04 ; \mathrm{F}_{1,30}=1.40 ; \mathrm{P}>0.05$ for mesotrophic site). Although, individuals who had higher body $\mathrm{P}$ content

Tab. 1. Nutrient concentration and trophic state index of the ultraoligotrophic Curu river and the mesotrophic Xixá reservoir, Northeastern Brazil.

\begin{tabular}{lcc} 
Nutrients & Curu River & Xixá Reservoir \\
Ammonium $\left(\mathrm{mg} \mathrm{L}^{-1}\right)$ & 0.03 & 0.21 \\
Nitrate $\left(\mathrm{mg} \mathrm{L}^{-1}\right)$ & 15.47 & 2.11 \\
\hline Nitrite $\left(\mathrm{mg} \mathrm{L}^{-1}\right)$ & 0.04 & 75.88 \\
Orthophosphate $\left(\mathrm{mg} \mathrm{L}^{-1}\right)$ & 0.63 & 0.31 \\
\hline Total phosphorus $\left(\mathrm{mg} \mathrm{L}^{-1}\right)$ & 41.2 \\
Chlorophyll $a\left(\mathrm{mg} \mathrm{L}^{-1}\right)$ & 4.6 & 36.53 \\
\hline Dissolved oxygen $\left(\mathrm{mg} \mathrm{L}^{-1}\right)$ & 61.33 & 2.1 \\
TSI (chlorophyll $a)$ & 23.65 & 47.09 \\
\hline TSI (total phosphorus) & 42.49 & 64.83 \\
TSI total & Ultraoligotrophic $($ IET $\leq 47)$ & Mesotrophic $(52<$ IET $\leq 59)$
\end{tabular}

TSI, trophic state index. 
were those with intermediate size (between 12 and $14 \mathrm{~cm}$ from the ultraoligotrophic site and between 11 and $13 \mathrm{~cm}$ from mesotrophic site) (Fig. 1).

\section{DISCUSSION}

The fish from the ultraoligotrophic site showed better body conditions, bigger sizes, and higher body $\mathrm{P}$ content. This suggests that $H$. jaguribensis does not show strict homeostasis, but that its body P content could be affected by environmental and/or physiological factors. Our results showed higher body $\mathrm{P}$ in fish collected in the ultraoligotrophic site, which had low phosphorous concentration in the water column. In the early stages of the armored catfish Megalechis personata, calcium accumulated twice as fast and phosphorus 1.5 times as fast in environments with low nutrient concentrations than in high nutrient concentrations (Mol et al., 1999). The higher body P content of fishes from our ultraoligotrophic site could be reflecting the pattern of faster mineral accumulation in environments with low nutrient concentrations (Mol et al., 1999). A correlation between body elemental composition and environmental characteristics was found in the European fish Rutilus rutilus, where body $\% \mathrm{P}$ and $\% \mathrm{~N}$ was negatively correlated with lake productivity (Boros et al., 2012). However, the authors found no relationship between $\% \mathrm{P}$ and body condition.

In our study, besides higher P content in their bodies, fish from the ultraoligotrophic site showed better body conditions. This suggests that environmental conditions could be influencing the physiological status of the species. The habitat characteristics in this site (e.g. presence of shelter, mesohabitat heterogeneity and substrates) could be allowing fish to have better body conditions, since these characteristics directly influence the availability of food and reproduction success (Duarte et al., 2011; Mazzoni et al., 2010). Catfishes are very often associated with rocky substrates, both favouring feeding and reproduction (Casatti et al., 2005; Duarte et al., 2011). Thus, the river habitat in the ultraoligotrophic site can be favouring better physiological conditions compared to the mesohabitat site, which is located in a reservoir. At this point, we are not able to discern the mechanisms that are causing the observed differences in body stoichiometry between fish populations from the two sites. We do not know if the observed differences in body P are a direct or indirect through a change in the physiological status - conse- quence of environmental differences. Studies in controlled conditions can help discern the causes.

The $\mathrm{P}$ body composition of loricariids from our study sites was on average between 3\% (mesotrophic Xixá reservoir) and 4.7\% (ultraoligotrophic Curu River), which are in the lower range of what has been reported for other species of the family. Vanni et al. (2002) reported $\mathrm{P}$ body values for Loricariidae fishes to vary between $4 \%$ and $6 \%$. Other species within the family (Ancistrus triradiatus and Chaetostoma milesi) have been reported to show body $\mathrm{P}$ values of approximately $4.5 \%$ (Hood et al., 2005), while the Mexican invasive sailfin catfish Pterygoplichthys sp. presented an average P value of 5.7\% (Capps and Flecker, 2013). Our results are in agreement with those found for some of these Loricari-

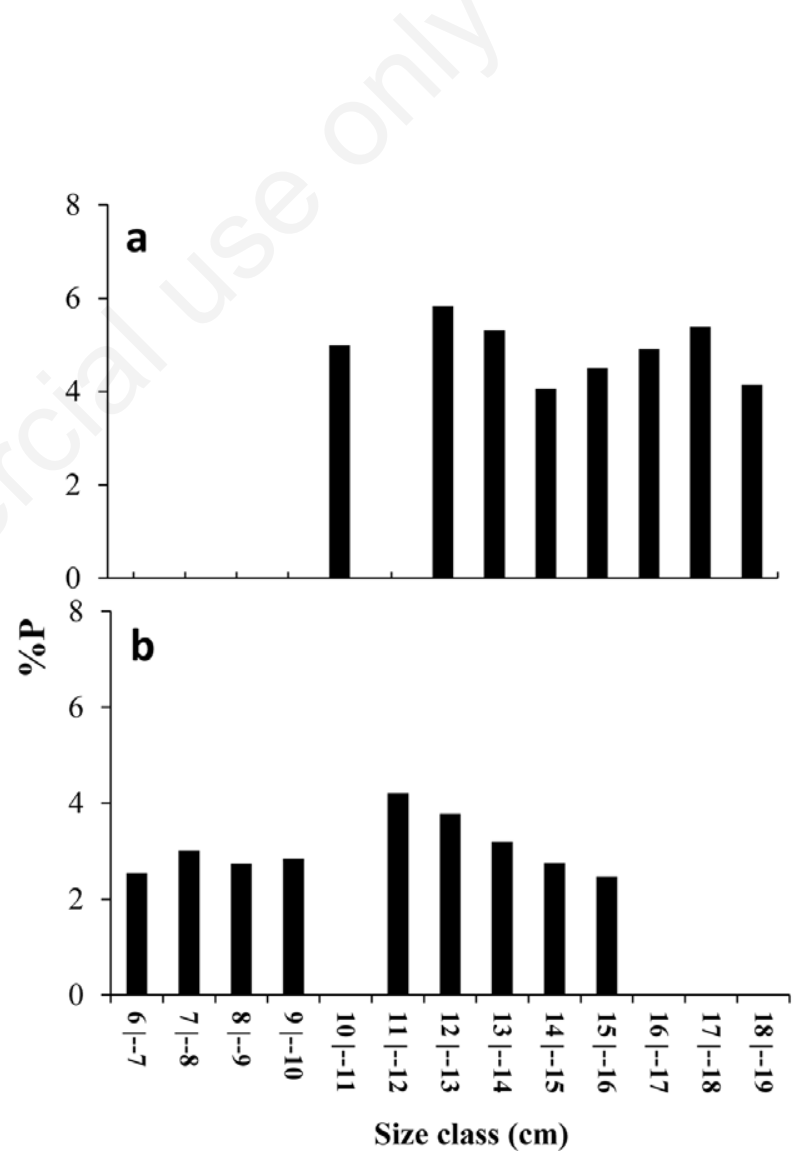

Fig. 1. Histogram of the P content (\%) in Hypostomus jaguribensis from the ultraoligotrophic Curu River (a) and the mesotrophic Xixá reservoir (b) by size class.

Tab. 2. \% Pody content, weight, and condition factor (CF) for H. jaguribensis from the two studied sites, the mesotrophic Xixá reservoir and the ultraoligotrophic Curu River. Values in parenthesis are \pm standard deviation.

\begin{tabular}{llll} 
& $\% \mathrm{P}$ & Weight $(\mathrm{g})$ & \\
Ultraoligotrophic & $4.72(1.24)(\mathrm{N}=26)$ & $91.84(28.88)(\mathrm{N}=31)$ & $0.067(0.008)$ \\
Mesotrophic & $3.02(0.87)(\mathrm{N}=32)$ & $42.93(24.93)(\mathrm{N}=32)$ & $0.026(0.003)$ \\
\hline
\end{tabular}


idae species, although some fishes from the mesotrophic site presented body P values of less than $2 \%$. Further research should address the reasons why $H$. jaguribensis shows lower \% $\mathrm{P}$ compared to other loricariids.

Increase in body $\mathrm{P}$ content during growth can be explained by two processes. $P$ content increases with growth due to its allocation in the bone tissue as a consequence of increased size (Sterner and Elser, 2002). Additionally, during growth, the demand for rRNA biosynthesis, which are P-rich molecules, increases due to high ribosomal complement for extensive protein synthesis, resulting in higher $\mathrm{P}$ content in rapidly growing animals (growth rate hypothesis; Elser et al., 1996) (Vrede et al., 2011). In large animals, however, P-demand could be much higher for bone construction than for rRNA synthesis (Sardans et al., 2012), due to the high storage of $\mathrm{P}$ and $\mathrm{Ca}$ in bone structure (Pilati and Vanni, 2007). A recent study showed that $P$ demand in two species of fish changed through ontogeny, being mostly driven by RNA synthesis in post-embryos stages and by bone construction in subsequent stages (Boros et al., 2015). We were expecting to find higher $\% \mathrm{P}$ in smaller fish, due to both rRNA demand and increased bone construction, instead, especially in the mesotrophic site, smaller fish had the lowest \%P values. Also, fish size showed no direct association with $\mathrm{P}$ body content but rather a potential $\mathrm{P}$ incorporation peak. In fact, for both sites, greater body $\% \mathrm{P}$ in individuals with intermediate sizes was observed. These results suggest that there is no continuous increase or decrease in $\mathrm{P}$ assimilation for these fish. The higher P content in between 11 and $14 \mathrm{~cm}$ can be related to biological characteristics of the species. The maturation of most species of the genus Hypostomus happens between 10 and $19 \mathrm{~cm}$ (Mazzoni and Caramaschi, 1995). Thus, the higher $\mathrm{P}$ body content between 11 and $14 \mathrm{~cm}$ can be explained as the need to accumulate nutrients at the beginning of the reproductive period.

\section{CONCLUSIONS}

Our study contributes to the growing body of research showing a deviation from strict stoichiometric homeostasis in fish (Hendrixson et al., 2007; Boros et al., 2012; ElSabaawi et al., 2012a,b, 2014; Benstead et al., 2014). The loricariids fish $H$. jaguribensis showed variations in its body P content, which were associated to environmental and physiological differences between sites. In the mesotrophic site, fish had lower P body content, worse body conditions, and smaller sizes. Differences in the organismal stoichiometry of populations from sites with different trophic status can lead to variations in the fish excretion rates, thus potentially affecting their role as nutrient recyclers. In disturbed sites, the ecological function of the species can change, with potential implications for the functioning of the ecosystem (Capps and Flecker, 2013; Spooner et al., 2013). Future studies should inves- tigate if the trophic status of the environment has a direct or indirect effect on the fish body stoichiometry, to pin point the mechanisms generating the observed differences.

\section{ACKNOWLEDGMENTS}

This paper is part of the first author's Master's Dissertation submitted to the Programa de Pós-Graduação em Ecologia e Recursos Naturais, Universidade Federal do Ceará. TMAS received a scholarship from the Coordenação de Aperfeiçoamento de Pessoal de Nível Superior (CAPES). BFT received a scholarship from Conselho Nacional de Desenvolvimento Científico e Tecnológico (CNPq) and Fundação Cearense de Apoio ao Desenvolovimento Científico e Tecnológico (FUNCAP). We thank André Porfírio, Frederico Alekhine, Lucas Moura, Raphaela Batista dos Santos, and Marcos de Miranda Leão Leite for their help with field and lab work.

\section{REFERENCES}

Benstead JP, Hood JM, Whelan NV, Kendrick MR, Nelson D, Hanninen AF, Demi LM, 2014. Coupling of dietary phosphorus and growth across diverse fish taxa: a meta-analysis of experimental aquaculture studies. Ecology 95:2768-2777.

Boros G, Jyväsjärvi J, Takács P, Mozsár A, Tátrai I, Søndergaard M, Jones RI, 2012. Between-lake variation in the elemental composition of roach (Rutilus rutilus L.). Aquat. Ecol. 46:385-394.

Boros G, Saly P, Vanni MJ, 2015. Ontogenetic variation in the body stoichiometry of two fish species. Oecol. 179:329-341.

Capps KA, Flecker AS, 2013. Invasive Fishes Generate Biogeochemical Hotspots in a Nutrient-Limited System. PLoS ONE 8:e54093.

Carlson RE, 1977. A trophic state index for lakes. Limnol. Oceanogr. 22:361-369.

Casatti L, Rocha FC, Pereira DC, 2005. Habitat use by two species of Hypostomus (Pisces, Loricariidae) in southeastern Brazilian streams. Biota Neotrop. 5:157-165.

Dalton CM, Flecker AS, 2014. Metabolic stoichiometry and the ecology of fear in Trinidadian guppies: consequences for life histories and stream ecosystems. Oecologia 176:69-701.

Duarte S, Araujo FG, Bazzoli N, 2011. Reproductive plasticity of Hypostomus affinis (Siluriformes: Loricariidae) as a mechanism to adapt to a reservoir with poor habitat complexity. Zoologia (Curitiba) 28:577-586.

Eaton AD, Clesceri LS, Rice EW, Greenberg AE, 2005. Standard methods for the examination of water and wastewater. 21. American Public Health Association, Washington DC: 110 pp.

El-Sabaawi RW, Kohler TJ, Zandonà E, Travis J, Marshall MC, Thomas SA, Reznick DN, Walsh M, Gilliam JF, Pringle C, Flecker AS, 2012a. Environmental and organismal predictors of intraspecific variation in the stoichiometry of a neotropical freshwater fish. PLoS One 7:e32713.

El-Sabaawi RW, Travis, J, Zandonà, E, McIntyre, PB, Reznick, DN, Flecker A, 2014. Intraspecific variability modulates interspecific variability in animal organismal stoichiometry. Ecol. Evol. 4:1505-1515. 
El-Sabaawi RW, Zandonà E, Kohler TJ, Marshall MC, Moslemi JM, Travis J, López-Sepulcre A, Ferriére R, Pringle CM, Thomas SA, Reznick DN, Flecker AS, 2012b. Widespread intraspecific organismal stoichiometry among populations of the Trinidadian guppy. Funct. Ecol. 26:666-676.

Elser JJ, Dobberfuhl DR, Mackay NA, Schampel JH, 1996. Organism size, life history, and N:P stoichiometry: toward a unifield view of cellular and ecosystem processes. BioSci. 46:674-684.

Froese R, 2006. Cube law, condition factor and weight-length relationships: history, meta-analysis and recommendations. J. Appl. Ichthyol. 22:241-253.

Gorayeb A, Souza MJN, Figueiredo MCB, Araújo LFP, Rosa MF, Silva EV, 2006. Sanitation and environmental impacts in the River Basin Curu - Ceará State - Northeastern Brazil. Rev. Elect. Geog. Cienc. Soc. 10:1-22.

Hendrixson HA, Sterner RW, Kay AD, 2007. Elemental stoichiometry of freshwater fishes in relation to phylogeny, allometry and ecology. J. Fish Biol. 70:121-140.

Hood JM, Vanni MJ, Flecker AS, 2005. Nutrient recycling by two phosphorus-rich grazing catfish: the potential for phosphorus-limitation of fish growth. Oecologia 146:247-257.

Mazzoni R, Caramaschi EP, 1995. Size structure, sex ratio and onset of sexual maturity of two species of Hypostomus. J. Fish Biol. 47:841-849.

Mazzoni R, Rezende CF, Manna LR, 2010. Feeding ecology of Hypostomus punctatus Valenciennes, 1840 (Osteichthyes, Loricariidae) in a costal stream from Southeast Brazil. Braz. J. Biol. 70:569-574.

McIntyre PB, Flecker AS, 2010. Ecological stoichiometry as an integrative framework in stream fish ecology. Am. Fish Soc. Symp. 73:539-558.

Mol JH, Atsma W, Flik G, Bouwmeester H, Qsse JWM, 1999. Effect of low ambient mineral concentrations on the accumulation of calcium, magnesium and phosphorus by early life stages of the air-breathing armoured catfish Megalechis personata (Siluriformes: Callichthyidae). J. Exp. Biol. 202:2121-2129.

Pilati A, Vanni MJ, 2007. Ontogeny, diet shifts, and nutrient stoichiometry in fish. Oikos. 116:1663-1674.

Sardans J, Rivas-Ubach A, Peñuelas J, 2012. The elemental sto- ichiometry of aquatic and terrestrial ecosystems and its relationships with organismic lifestyle and ecosystem structure and function: a review and perspectives. Biogeochemistry. 111:1-39.

Spooner DE, Frost PC, Hillebrand H, Arts MTPO, Xenopoulos MA, 2013. Nutrient loading associated with agriculture land use dampens the importance of consumer-mediated niche construction. Ecol. Lett. 16:1115-1125.

Stainton MP, Capel MJ, Armstrong FAJ, 1977. The chemical analysis of fresh-water. Miscellaneous Special Publication. 25. Freshwater Institute, Winnipeg: $180 \mathrm{pp}$.

Sterner RW, Elser JJ, 2002. Ecological stoichiometry: the biology of elements from molecules to the biosphere. Princeton University Press: 440 pp.

Toledo Jr AP, Talarico M, Chinez SJ, Agudo EG, 1983. [A aplicação de modelos simplificados para a avaliação de processp da eutrofização em lagos e reservatórios tropicais].[Article in Portuguese]. Proc. $12^{\circ}$ Cong Brasileiro de Engenharia Sanitária. Camboriú, Associação Brasileira de Engenharia Sanitária. Camboriú (SC), Brazil.

Vanni MJ, Flecker AS, Hood JM, Headworth JL, 2002. Stoichiometry of nutrient recycling by vertebrates in a tropical stream: linking species identity and ecosystem processes. Ecol. Lett. 5:285-293.

Vanni MJ, 2002. Nutrient cycling by animals in freshwater ecosystems. Annu. Rev. Ecol. Syst. 33: 341-370.

Vanni MJ, Boros G, McIntyre PB, 2013. When are fish sources vs. sinks of nutrients in lake ecosystems?. Ecology 94:21952206.

Vrede T, Dobberfuhl DR, Kooijman S, Elser JJ, 2004. Fundamental connections among organism C:N:P stoichiometry, macromolecular composition, and growth. Ecology 85: 1217-1229.

Vrede T, Drakare S, Eklov P, Hein A, Liess A, Olsson J, Persson J, Quevedo M, Stabo HR, Svanback R, 2011. Ecological stoichiometry of Eurasian perch - intraspecific variation due to size, habitat and diet. Oikos 120:886-896.

Zagatto PA, Lorenzetti ML, Lamparelli MC, Salvador ME, Menegon Jr N, Bertoletti E, 1999. Improvement of a water quality index. Acta Limnol. Bras. 11:111-126. 